\title{
Exempel på gångformigt uppträdande hälleflinta
}

\section{A. Sjögren}

To cite this article: A. Sjögren (1872) Exempel på gångformigt uppträdande hälleflinta, Geologiska Föreningen i Stockholm Förhandlingar, 1:5, 86-88, DOI: 10.1080/11035897209443819

To link to this article: http://dx.doi.org/10.1080/11035897209443819

$$
\text { 曲 Published online: 06 Jan } 2010 .
$$

Submit your article to this journal $\pi$
Џll Article views: 5 
salt ( $\left.\dot{\mathrm{Ca}}^{3} \ddot{\hat{P}}\right)$, salht kloren såsom klorcalcium och öfverskottet af kalk såsom fluorcalcium, hvilket är sannolikit, di̊ mineralet ger tydliga fluorreaktioner, erháller mineralet följande 'sạmmansïttning:

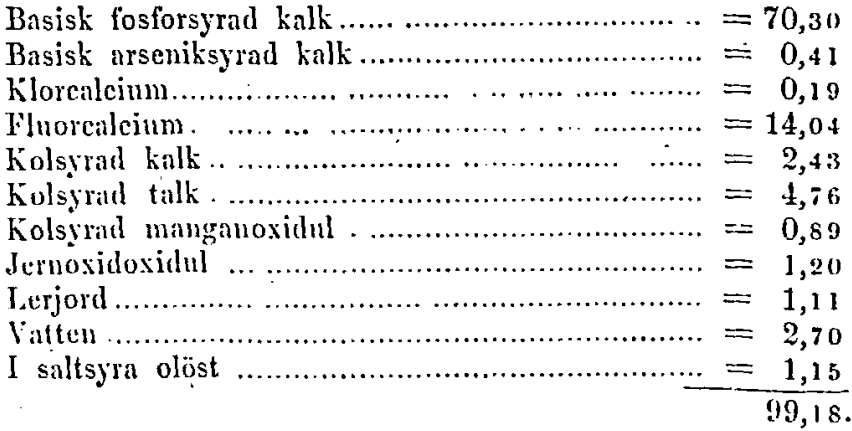

Pi̊ en eqvivalent klor- och fluorealcium kommer $1 \frac{1}{4} \mathrm{eq}$. basisk fosfursyrad kalk. Som dock profvet, som analyserades, icke var rent och tydligen hade undergått en viss sönderdelning, torde man icke af denua analys med sïkerhet kuma bestämma mineralets formel.

Fïstes intet afseende vid de kolsyrade salterna skulle formelu blifin:

$$
\pm \mathrm{Ca}\left\{\begin{array}{l}
\mathrm{Fl} \\
\mathrm{Cl}
\end{array}+5 \dot{\mathrm{Ca}^{3}}\left\{\begin{array}{l}
\ddot{\hat{p}} \\
\ddot{\mathrm{As}}
\end{array}\right.\right.
$$

Det i klorvätesyra olösta innehöll hufvudsakligen kiselsyra. Kall utspïdd ättiksyra utdrager de kolsyrade salterna. Utspädd salpetersyra (1 syra med 10 vatten) löser mineralet med lemning af en återstod, som vaigde 2,70 procent och innehöll mycket fluorcalcium.

SJỏGREN, A. Exempel på gångformigt uppträdande hälleflinta.

Det är kändt, att hälleflintan å Dannemora grufvefält förekommer under många vexlande former. Der finnes randig hälleflinta, tät hälleflinta och qvartsprickig hälleflinta. Under en grufbefaring derstädes sistlidne löst hade jag tillfälle att $i$ sö̈dra Silf bergsgrufvans fältort $i$ söder» iakțaga, att en af tät grund- 
massa bestående hälleflinta der förekommer gångformigt afskiirande de nära lodrätt stående och med tydlig randning försedda kalklagren, hvilka, si̊som vanligt i fältet, äro uppblandade mer eller mindre. med granat- och pyroxenarter i smalare och bredare band." Se vidstående figur.

A. ERdmaxx anfür $\mathbf{i}$ ”Beskrifning öfver Dannemora jernmalmsfïltm, K. Tet.Ak. IIandl. 1850, de olika hitlleflintoma vid Dannemora och upptager derrid:

a) Den lagerformiga hälleflintan, hvari jernmalmsdepositionerna finnas inneslutne, och som stundom öfvergảr $\mathrm{i}$ den frản dessa grufvor så väl bekanta randiga hälleflintan, en omvexling af olika fär- $b$ ) Tät hälleflinta. gade hälleflintor $\mathrm{i}$ tunnare eller tjockare lager. „Denna sednare förekommer lagervis i kalk».

b) Liggande eller sväfvande hälleflintskölar, som afskära malmen och intill denna üro begränsade af chlorit, samt delvis ersättas af samma mineral. Dessa betraktades såsom utlöpare i olika riktningar från den omgifvande lagerformiga lälleflintan. Derom yttras sid. 48: „Dessa skölar af chlorit och hälleflinta äro uppenbarligen inga rerkliga gångar, utan ifyllningar mellan malmstockens afsündringsytor, saimt utan tvifvel bildade liktidigt eller nära liktidigt med denna,»

Den i södra Silf bergsgrufvan lagren afskärande hälleflintan är tät, gråaktig, med insprängda korn af svafvelkis, temligen förklyftad och på afsöndringsytorna öfverdragen med en chlorithinụa.

Det kan icke nekas, att en viss analogi förefinnes emellan den vid Dannemora tillhopa med chlorit uppträdande hälleflintan och de på andra grufvefält (t. ex. Falun och Persberg) uppträdande, malmlagren öfvertvärande, s. k. trappgångarne, hvilka, såvidt jag känner, icke närmare blifvit undersökta. Man har antagit dem vara dioriter eller diabaser, men de synas med mera sannolikhet bestå af chlorit- eller hornblendearter, hvilka tillkommit efter det att malmlagren intagit sin nuvarande ställning, 
men i afseende på sina kemiska beståndsdelar dock äga ett visst beroende af malmlagren med dess omgifrande gang- och bergarter.

NaUcknoff, G. Kopparhaltig Geokronit frian Björkskogsncis.

Vid Björkskogsnäs kalkbrott, belïget i Grythytte socken af Örebro län, vid Svartelfvens utlopp ur sjön Torrvarpen, fürekomma $\mathrm{i}$ en finkristallinisk dolomit itshilliga für denna bergart ovanligare accessoriska mineralier.

Främsta rummet bland dessa intager ett svart, glïnsande, derbt mineral, insprängdt i mindre partier och vanligen omgifvet af ett' blått eller grönt omhölje af kopparlazur eller malachit, och som vid analys risade sig vara en ovanligt kopparhaltig geokronit.

För at befria mineralet frîn vidhängande dolomit behandlades pulvret med ättiksyra.

Analysen gaf:

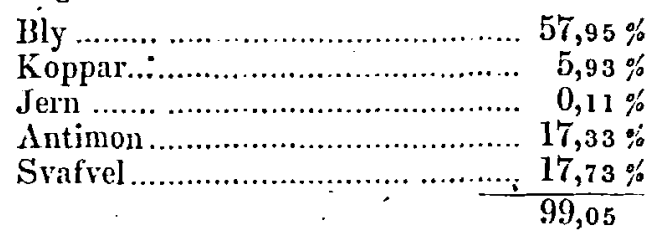

livaraf erhålles formeln:

$$
\left.\begin{array}{r}
\mathrm{Pb} \\
5 \mathrm{Cu} \\
\mathrm{Fe}
\end{array}\right\} \mathrm{S} \cdot \mathrm{Sb} \mathrm{S}_{3} \text {. }
$$

Mineralet äj fullkomligt derbt, nästan srart, glänsande, ogenomskinligt. Pulrret svart. Brottet ojemnt, skåligt. Egentliga vigten $=6,26$.

För blåsrör smälter lätt och ger reaktion für bly, hoppar, antimon och 'svafiel.

Dessutom förekomma zinkblende, grammatit och finfjällig talk. Stundom är bergarten färgad intensivt blå eller grön af de genom geokronitens sönderdelning bildade kopparkarbonaterna. 